\title{
ARTIGOS
}

\section{Characterization of Citrus tristeza virus isolates from grapefruit (Citrus paradisi Macf.) accessions of Citrus Active Germplasm Bank}

\author{
Maria Júlia Corazza-Nunes 1,5, Marcos Antonio Machado², Dagmar Ruth Stach-Machado², William Mário Carvalho \\ Nunes $^{4,5}$, Sérgio Alves de Carvalho ${ }^{2} \&$ Gerd Walter Müller
}

${ }^{1}$ Depto. de Biologia, Universidade Estadual de Maringá. 87020-900 Maringá, PR, Brazil. e-mail: mjcorazza@uem.com.br ²C.C.S.M.-IAC. Cordeirópolis, SP, Brazil. ${ }^{3}$ Depto. de Imunologia, Unicamp, Campinas, SP, Brazil. ${ }^{4}$ Depto. de Agronomia, UEM. Maringá, PR, Brazil. ${ }^{5}$ Núcleo de Pesquisa em Biotecnologia Aplicada - Universidade Estadual de Maringá - NBA/UEM.

Data de chegada: 19/07/2005. Aceito para publicação em: 23/01/2006.

\begin{abstract}
Corazza-Nunes, M.J.; Machado M.A.; Stach-Machado, D.R.; Nunes, W.M.C.; Carvalho, S.A.; Müller, G.W. Characterization of Citrus tristeza virus isolates from grapefruit (Citrus paradisi Macf.) accessions of Citrus Active Germplasm Bank. Summa Phytopathologica, v.32, n.4, p.322-327, 2006.

Citrus tristeza virus (CTV) isolates from 35 grapefruit accessions belonging to Citrus Active Germplasm Bank of the "Instituto Agronômico de Campinas" located at the "Centro APTA Citros Sylvio Moreira”, Cordeirópolis, São Paulo state, Brazil, were characterized and evaluated through symptoms in the trees, biological indexing, immunological diagnosis with different monoclonal antibodies and SSCP analysis (single-strand conformation polymorphism) of the coat protein gene. Symptomatology indicated that, in general, the group of plants with smaller canopy volume and severe stem pitting differed significantly from the group that presented greater vegetative development and mild to moderate stem pitting. However, the isolates from most of the accessions induced mild

reaction on Mexican lime. The serological evaluation through the DAS-ELISA using monoclonal antibodies did not reveal any association between virus titer in the plant tissue and symptoms. The reaction with different monoclonal antibodies and the distinct electrophoresis patterns obtained through SSCP showed that there is a high degree of diversity among the isolates that infect these grapefruit accessions. High complexity within the same isolate was also observed in the SSCP profiles. This finding indicates that the CTV isolates from these plants are a complex mixture of CTV haplotypes. Similar SSCP banding patterns were observed among some plants with strong stem pitting symptoms, and among some plants with weak or moderate stem pitting symptoms.
\end{abstract}

Additional keywords: ELISA, monoclonal antibodies, single-strand conformation polymorphism

\section{RESUMO}

Corazza-Nunes, M.J.; Machado M.A.; Stach-Machado, D.R.; Nunes, W.M.C.; Carvalho, S.A.; Müller, G.W. Caracterização de isolados do vírus da tristeza dos citros de acessos de pomelos (Citrus paradisi Macf.) do Banco Ativo de Germoplasma de Citros. Summa Phytopathologica, v.32, n.4, p.322-327, 2006 .

Isolados do vírus da tristeza dos citros (CTV) de 35 acessos de pomelos que fazem parte do Banco Ativo de Germoplasma de Citros, localizado no Centro APTA Citros Sylvio Moreira, Cordeirópolis, São Paulo, Brasil, pertencente ao Instituto Agronômico de Campinas (IAC), foram caracterizados através dos sintomas observados nas árvores, indexação biológica, diagnóstico imunológico e análise SSCP (polimorfismo de conformação de fita simples) do gene da proteína do capsídeo. O grupo de plantas que, em geral, apresentou menor volume de copa e severo sintoma de canelura diferenciou-se significativamente do grupo com maior desenvolvimento vegetativo e fraco a moderado sintoma de canelura. No entanto, a maioria dos isolados de CTV das plantas de ambos os grupos induziu fraca reação em limão galego e nenhuma relação entre títulos do vírus nos tecidos e sintomatologia foi observada na avaliação sorológica conduzida por DAS-ELISA. A reação com diferentes anticorpos monoclonais e os distintos padrões eletroforéticos obtidos por SSCP demonstraram que há uma grande diversidade entre os isolados de CTV que infectam os acessos de pomelos. Alta complexidade de bandas dentro de um mesmo isolado foi também observada nos perfis SSCP, demonstrando que cada isolado é constituído por uma mistura de diferentes haplótipos de CTV. Padrões SSCP semelhantes foram observados entre algumas plantas com fortes sintomas de caneluras e entre algumas plantas com sintomas fracos ou moderados de caneluras. 
The Citrus Active Germplasm Bank (Citrus-AGB) of "Instituto Agronômico de Campinas" (IAC), located at the "Centro APTA Citros Sylvio Moreira”, Cordeirópolis, State of São Paulo, Brazil, was initiated in 1930 and is one of the most important citrus collections of the world (7).

The collections were increased and renewed along the years, serving as material source for research and production of new scion and rootstock varieties to the Brazilian citriculture $(14,22)$. Nowadays the IAC Citrus-AGB has 1.750 accessions being 59 out of them represented by different grapefruit varieties (Citrus paradisi Macf) grafted on Cleopatra mandarin (C reshni Hort. Ex Tan.) (5).

In Brazil the grapefruit production is small because this fruit is not popular besides being susceptible to the Citrus tristeza virus (CTV). They were probably the first citrus plants to show altered growth and development when infected by CTV even on tolerant rootstocks (16). The most evident tristeza symptoms for these cultivars are reduced growth and development, small fruits and thick rinds, and especially the presence of stem pitting in young branches and twigs. However, the possibility to exploit some commercial niches requires vigorous and productive groves. In this perspective, the characterization of CTV isolates of some grapefruit accesses of the Citrus-AGB to find out those naturally infected with mild isolates could contribute to the selection of mother trees with commercial potential.

The procedures more often used for these purposes involve biological indexing $(3,5)$; immunological methods via different monoclonal antibodies $(12,20,24,25)$; dsRNA (double-strand RNA) analysis (17); restriction fragment length polymorphism (RFLP) $(9,30)$, reverse transcription-polymerase chain reaction (RT-PCR) (10), and single-strand DNA conformation polymorphism (SSCP) $(4,6,27)$.

In this study CTV isolates from 35 grapefruit accessions belonging to IAC Citrus-AGB were characterized and evaluated through tristeza symptoms in the tree, biological indexing, immunological diagnosis with different monoclonal antibodies, and SSCP analysis of the coat protein gene.

\section{MATERIALS AND METHODS}

Virus isolates and plant materials. The CTV isolates were obtained from 35 grapefruit accessions, which belong to the new and old clone collection from the IAC Citrus-AGB (Table 1). The plants had about 10 years when evaluated. The evaluation of tristeza symptomatology and serological analysis were carried out on three repetitions of each access. The biological indexing and molecular analyses were done with one clone of each access.

Evaluation of tristeza symptomatology. Stem pitting symptoms were evaluated by peeling of the bark from $15 \mathrm{~cm}$ long segments, cut from young twigs, which were sampled from the North, South, East and West quadrants in a total of four segments for plant. A rating scale (15), from 0 to 5, was used to quantify the presence of the stem pitting, where: $0=$ no stem pitting, $1=1$ to 15 stem pits, $2=16$ to 30 stem pits, $3=31$ to 50 stem pits, $4=51$ to 80 stem pits and $5=$ the total segment was covered with stem pits. The plant growth and development was calculated by evaluating the canopy volumes by the formula: $V=2 / 3 \pi R^{2} H$ (23). Tukey's HSD test $(\mathrm{P} \geq 0.05)$ was used to verify the correlation between canopy volume and stem pitting intensity.
Biological indexing. The biological indexing was conducted under greenhouse conditions. The indicator plants were prepared by grafting two buds from every one of the 35 source trees and one bud from a healthy Mexican lime (C aurantifolia Swing.) onto a Rangpur lime ( $C$ limonia Osbeck) rootstock. Each test had five plants with positive and negative controls. CTV symptoms (presence and intensity of vein clearing) on the indicator plants were evaluated two to four months after grafting. They were characterized according to Carvalho et al. (5) as: mild $(+)$ (very faint traces of vein clearing); severe $(++)$ (vein clearing); and very severe $(+++)$ (intensive vein clearing up to the point of vein suberization and leaf curling).

ELISA. The serological analyses and purification of virus dsRNA were processed from the bark of young branches, which were taken around the canopy and combined to make one sample. The DASELISA (double antibody sandwich indirect enzyme-linked immunosorbent assay) was applied according to Garnsey \& Cambra (8). The polyclonal antibodies PCA 1006/ $\mathrm{Br}$ (1:10.000 dilution), monoclonal antibodies (MAbs) 30E-09, 37D-09 and 39-09 (1:10.000 dilution) were produced from recombinant proteins obtained from the coat protein of severe Brazilian isolates (31) and MCA-13 to the T36 isolate of CTV from Florida (1:15.000 dilution) (21). The PCA $1006 / \mathrm{Br}$ was used to cover the plates, while the MAbs were used as a second antibody. Approximately $0.1 \mathrm{~g}$ of fresh tissue was prepared by grinding and homogenizing in $2 \mathrm{ml}$ of phosphate buffer, $\mathrm{pH} 7.4$, containing $0.5 \mathrm{ml} / 1$ tween 20 (PBST) and $20 \mathrm{~g} / 1$ polyvinylpyrrolidone (PVP-40) at 1:20 (w/v) dilution. Extracts from healthy and infected plants were utilized as negative and positive controls, respectively. The assay had two repetitions per sample and was evaluated after $3 \mathrm{~h}$ of incubation. The plates were read with a BioRad ELISA Plate Reader at a $405 \mathrm{~nm}$ wavelength. The samples were considered positive if the optical density was higher three times greater than the mean of healthy controls (21).

Purification of CTV dsRNA. The dsRNA was extracted from CTV infected lyophilized tissue according to Valverde et al. (33). Phenol, chloroform-isoamyl alcohol (24:1), SDS (sodium dodecyl sulfate) and 2X STE extraction buffer $(1 \mathrm{x}$ STE $=0.05 \mathrm{mM}$ Trisma base; 0.1 M NaCL; $1 \mathrm{mM}$ EDTA pH: 6.8) were used. Afterwards, the dsRNA was purified through two cycles of chromatography with cellulose columns (Whatman CF 11).

cDNA synthesis and PCR amplication. The dsRNA was denatured at $94^{\circ} \mathrm{C}$ for $5 \mathrm{~min}$ and used as templates for the synthesis of the first strand cDNA of the coat protein gene (CPG). This procedure was carried out according to Sambrook et al. (28) with modifications. The amplification of the CPG region was done with primers CN-119-CTV (5, AGATCTACCATGGACGACGAAACAAAG 3') and CN-120-CTV (5' GAATTCGCGGCCGCTCAACGTGTGTTAAATTTCC 3'), which were derived from the tristeza T-36 haplotypes from Florida, USA (32). The amplifications were performed in a MJ thermocycler, programmed for 35 cycles of $1 \mathrm{~min}$ at $94^{\circ} \mathrm{C}$ (denaturation), followed by $1 \mathrm{~min}$ at $55^{\circ} \mathrm{C}$ (annealing), and $2 \mathrm{~min}$ at $72^{\circ} \mathrm{C}$ (DNA synthesis) followed by a final extension at $72^{\circ} \mathrm{C}$ for $5 \mathrm{~min}$. The final CPG product was purified in $0.8 \%$ low melting agarose.

SSCP analysis. For the SSCP analysis of the 35 CTV isolates, 1$5 \mu \mathrm{L}$ of the amplified CPG purified fragments were mixed with an equal volume of denaturing solution $(95 \%$ de formamide, $2 \mathrm{mM}$ de 
Table 1. Reactions of grapefruit accessions to the presence of CTV haplotypes via DAS-ELISA with monoclonal antibodies and to the CTV severity. Canopy volume and biological indexing analyses.

\begin{tabular}{|c|c|c|c|c|c|c|c|}
\hline \multirow{2}{*}{$\begin{array}{l}\text { Grapefruit } \\
\text { Accessions }\end{array}$} & \multicolumn{4}{|c|}{ Monoclonal antibodies } & \multirow{2}{*}{$\begin{array}{c}\text { CTV } \\
\text { Severety }\end{array}$} & \multirow{2}{*}{$\begin{array}{l}\text { Canopy } \\
\text { Volume } \\
\left(\mathrm{m}^{3}\right)\end{array}$} & \multirow{2}{*}{$\begin{array}{r}\text { Biologica } \\
\text { Indexing }\end{array}$} \\
\hline & $30 \mathrm{E}-09$ & MCA-13 & $37 \mathrm{D}-09$ & $39-09$ & & & \\
\hline \multicolumn{8}{|l|}{ Group 1* } \\
\hline OC 331-Viçosa & 2.348 & 1.162 & 1.318 & 1.381 & 5 & 0.6 & ++ \\
\hline OC 322-Marsh Seedless 11656 & 2.179 & 0.579 & 0.670 & 0.724 & 5 & 1.1 & ++ \\
\hline OC 323-Marsh Seedy & 2.277 & 0.900 & 0.866 & 1.088 & 4 & 2.8 & + \\
\hline NC 667-Redblush-Califórnia & 2.553 & 0.449 & 0.773 & 0.635 & 4 & 3.3 & + \\
\hline OC 317-Red Mexican & 2.371 & 1.378 & 1.040 & 1.150 & 4 & 4.6 & ++ \\
\hline NC 676-hybrid 47389 & 1.983 & 0.509 & 0.560 & 0.573 & 2 & 5.1 & + \\
\hline NC 670-Leonardy - Flórida & 1.469 & 0.232 & 0.277 & 0.312 & 4 & 5.1 & ++ \\
\hline OC 314-Royal & 2.234 & 0.338 & 0.467 & 0.405 & 4 & 5.1 & + \\
\hline OC 316-Redblush & 2.294 & 0.732 & 0.925 & 0.754 & 4 & 5.8 & + \\
\hline OC 333-Duncan & 2.390 & 0.913 & 0.998 & 1.061 & 4 & 5.8 & + \\
\hline OC 321-Marsh Seedless & 2.332 & 0.325 & 0.668 & 0.544 & 4 & 5.8 & ++ \\
\hline NC 345-Marsh da Florida & 2.569 & 0.723 & 0.735 & 0.698 & 4 & 5.9 & + \\
\hline NC 341-Coco Variação & 1.858 & 0.518 & 0.675 & 0.725 & 5 & 6.0 & + \\
\hline NC 342-Arananyan & 1.220 & 0.219 & 0.325 & 0.212 & 3 & 6.2 & + \\
\hline NC 668-Marsh Seedless - S.Sebastião & 2.222 & 0.273 & 0.505 & 0.323 & 5 & 6.6 & + \\
\hline OC 328-Foster & 2.212 & 0.993 & 1.020 & 1.212 & 2 & 6.7 & ++ \\
\hline NC 669-Marsh Seedless-Dieherger & 2.198 & 0.495 & 0.785 & 0.795 & 4 & 6.9 & + \\
\hline NC 331-Marsh Seedless & 2.410 & 0.520 & 0.593 & 0.437 & 4 & 6.9 & + \\
\hline OC 336-Leonardy & 2.104 & 0.525 & 0.666 & 0.752 & 2 & 7.5 & ++ \\
\hline NC 677-hybrid 47449 & 2.052 & 0.295 & 0.445 & 0.280 & 5 & 9.7 & + \\
\hline OC 334-Duncan & 1.987 & 0.172 & 0.405 & 0.214 & 2 & 10.7 & + \\
\hline Average & & & & & $3.8 \mathbf{a}^{1}$ & $5.6 \mathbf{a}$ & \\
\hline \multicolumn{8}{|l|}{ Group 2** } \\
\hline OC 320-Imperial & 2.190 & 0.271 & 0.639 & 0.414 & 1 & 14.1 & ++ \\
\hline OC 329-Retiro & 2.100 & 0.441 & 0.665 & 0.702 & 2 & 14.1 & + \\
\hline OC 335-Pernambuco & 2.295 & 1.252 & 1.108 & 1.158 & 2 & 15.2 & + \\
\hline OC 318-Triumph & 2.181 & 0.323 & 0.568 & 0.609 & 3 & 15.2 & + \\
\hline OC 332-Hart's & 2.452 & 0.515 & 0.810 & 0.945 & 2 & 16.8 & + \\
\hline OC 326-Cannores & 2.492 & 0.994 & 1.207 & 1.070 & 3 & 17.7 & + \\
\hline NC 346-Shamber da Florida & 2.435 & 0.181 & 0.426 & 0.365 & 3 & 18.8 & + \\
\hline NC 672-Mauritius & 2.430 & 0.223 & 0.800 & 0.405 & 1 & 21.1 & + \\
\hline OC 324-Mac Carthy & 2.447 & 0.694 & 0.783 & 0.903 & 1 & 22.0 & + \\
\hline NC 675-Siamesa - Filipinas & 2.336 & 0.616 & 0.582 & 0.450 & 1 & 24.7 & + \\
\hline OC 315-Rubi & 2.429 & 0.847 & 0.831 & 0.862 & 3 & 25.1 & + \\
\hline OC 319-Thompson Pink & 2.489 & 1.287 & 1.095 & 1.167 & 3 & 32.3 & + \\
\hline NC 673-Pamplemousse-Mauritius & 1.195 & 0.244 & 0.175 & 0.265 & 1 & 41.6 & + \\
\hline NC 678-Dalandan-Filipinas & 2.254 & 0.617 & 0.645 & 0.579 & 1 & 45.6 & + \\
\hline $\begin{array}{r}\text { Average } \\
\end{array}$ & & & & & $1.9 \mathbf{b}$ & $23.2 \mathbf{b}$ & \\
\hline Healthy plant & 0.039 & 0.023 & 0.015 & 0.013 & & & \\
\hline
\end{tabular}

*Group 1: plants with reduced canopy volumes and strong stem pitting symptoms. **Group 2: plants with high canopy volumes and mild stem pitting symptoms. ${ }^{1}$ Means followed by the same letter in the columns are not significantly different according to Tukey's HSD test $(\mathrm{P} \geq 0.05)$. 
EDTA and $0.05 \%$ bromophenol blue). The samples were heated for 10 min at $95^{\circ} \mathrm{C}$ and placed immediately on ice. The denatured CPG fragments were resolved in a $8 \%$ non-denaturing polyacrylamide gel containing TBE buffer (45 mM Tris-Boric, $1 \mathrm{mM}$ EDTA, pH 8,4). The electrophoresis was conducted at a constant voltage of $200 \mathrm{~V}$ for $7 \mathrm{~h}$ at $25^{\circ} \mathrm{C}$. Subsequently the gels were stained with silver nitrate based upon Beidler et al. (2).

\section{RESULTS AND DISCUSSION}

The results obtained from the immunological diagnosis, CTV severity, evaluated through of the stem pitting symptoms, canopy volume measurements and biological-indexing assays of CTV isolates from 35 grapefruit accessions are represented in Table 1. The stem pitting and canopy volume measurements represent the average of three repetitions.

CTV severity, vegetative development and biological indexing

Severe stem pitting symptoms (rating 4-5) were observed in approximately $46 \%$ of the grapefruit accessions of the old clone (OC) and of the new clone collections (NC) from AGB. The remaining plants showed mild $(1,2)$ to moderate $(3)$ stem pitting symptoms (Table 1).

Data from the canopy volume also indicated a great variation in vegetative development among the accesses of both collections, due to this, two groups were formed: group 1, where plants had canopy volume inferior to $11 \mathrm{~m}^{3}$ and in general severe stem pitting, and group 2 , plants with canopy volume superior to $11 \mathrm{~m}^{3}$ and mild to moderate stem pitting (Table 1). These groups differed significantly according to Tukey's HSD test $(\mathrm{P} \geq 0.05)$.

Many of the accessions that were placed into group 1, especially the varieties 'Viçosa', 'Marsh Seedless', 'Marsh Seedy', 'Redblush' and 'Red Mexican', were badly affected in their growth and showed severe stem pitting, probably due to infection by severe CTV isolates. However, some plants from this group had poor growth and showed mild stem pitting. This fact to mean that the growth of these plants was so seriously affected that didn't allow not even the expression of stem pitting symptom. Further, some factors other than the presence of CTV could have affected the canopy development.

On the contrary of group 1, the plants of group 2 had much better growth and less stem pitting, standing this out in the cases of accessions 'Dalandan', 'Pamplemousse', 'Siamesa', 'Mac Carthy' and 'De Maurítius', all with mild stem pitting symptoms and values for the canopy volume higher than for most of the other plants. A few accessions such as 'Rubi', 'Thompson Pink', and 'Shamber' had high canopy volume values even though they had moderate stem pitting symptoms.

Biological indexing results showed that the isolates from most of the 35 accessions induced mild reaction on Mexican lime, although some of these accessions ranged from moderate to severe stem pitting symptoms. On the other hand, others, which incited mild or moderate stem pitting symptoms, developed severe reactions on Mexican lime (Table 1).

These results confirm the hypothesis about the specificity of isolates in a complex when interacting with the host. Different studies have demonstrated that the expression of CTV symptoms vary according to the isolate severity as well as with the species of the indicator plant $(1,13)$. The Mexican lime is a sensitive indicator for the expression of vein clearing, leaf curling, dwarfism and stem pitting. However, these symptoms do not necessarily always reflect the severity of the isolates in other species and varieties of Citrus (26).

\section{ELISA}

For the serological evaluation (Table 1), it was observed that plants from both groups had a positive reaction with all monoclonal antibodies tested. This indicates the presence of different CTV isolates, which infected the grapefruit accessions from the AGB. Titers above 1.00 were noted in all plants, from both groups, with the monoclonal antibody 30E-09, which imply its universal properties.

The detection of CTV haplotypes by the MCA-13, 37D-09 and 39-09 specific monoclonal antibodies revealed that plants from Group 1 (those with reduced canopy volumes and strong stem pitting symptoms) as well as from Group 2 (those with high canopy volumes and mild stem pitting symptoms) had titer between 0.1 and 1.5. Therefore, no correlation was observed between the CTV severity and the detection by the antibodies. It confirms previous observations that these traits are not necessarily correlated $(12,24)$. According to Nickel et al. (17), field plants are often infected by a mixture of CTV haplotypes and the predominating haplotypes in an infected tree determine the symptomatology in the plant. The explanation of the results from plants with severe symptoms, but with low antibody detection, could be due to the absence of epitopes for their detection. Additionally, Powell et al. (24) argument that positive plants goes isolated severe of CTV cannot express symptoms during various years. By contrast, plants with strong decline symptoms can have their growth and development affected by other factors besides the presence of CTV.

The MAbs 37D-09 and 39-09 showed high titers (above 0.5) for a large number of accessions when compared to MCA-13. The MCA13 monoclonal antibody recognizes a linear epitope and selectively reacts with isolates that induce citrus decline in Florida (USA), however, it does not react with mild isolates (21). According to Pappu et al. (19), the reaction of MCA-13 depends upon the presence of phenylalanine amino acid in position 124 of the CTV coat protein gene. For Nikolaeva et al. (18), the MCA-13 is not able to distinguish isolates that cause decline from those that provoke stem pitting and it can fail to react with isolates that incite decline from regions outside of Florida. In Japan, Kano et al. (11) documented that this monoclonal antibody reacted with mild isolates. This Mab has also reacted with Brazilian mild isolates, and it is not able to recognize severe isolates (35).

In contrast, the MAbs 37D-09 and 39-09 obtained from recombinant coat protein extracted from the complex of severe isolates from 'Capão Bonito' (32) reacted with CTV isolates from various grapefruit accessions. This result suggests that these isolates and those from 'Capão Bonito' share the specific epitope of the coat protein recognized by MAbs 37D-09 and 39-09. Further, low titers with these antibodies were also observed in many plants with severe stem pitting symptoms.

\section{SSCP analysis}

The great diversity among CTV isolates, that infect grapefruit accessions from AGB, was also shown by the SSCP analysis (Figure 1). Through the number of bands and their positions, it was observed high heterogeneity in the SSCP profile pattern among isolates and high complexity within the same isolate. Considering that each band corresponds to one of the two DNA strands from the dsDNA obtained after RT-PCR, one to four haplotypes were observed in the CTV 
isolates infecting grapefruit accessions from IAC Citrus-AGB.

Similar electrophoresis patterns were documented among isolates from the following accession groups: between 'Rubi' (OC 315) and 'Red Mexican' (OC 317); among 'Redblush' (OC 316), 'Foster' (OC 328), 'Marsh da Florida'(NC 345), 'Redblush' (NC 667), 'Marsh Seedless S. Sebastião' (NC 668) and 'Marsh Seedless Limeira' (NC 669); among 'Marsh Seedless' (OC 321), 'Marsh Seedy' (OC 323), 'Cannores' (OC 326), 'Marsh Seedless' (NC 331), 'Coco Variação' (NC 341) and 'Arananyan' (NC 342). Almost all these accessions (except OC 315 and OC 326) belong to the group 1 and showed moderate to severe stem pitting symptoms (ranging 3-5). Only accession OC-328 showed mild stem pitting symptoms, but developed severe reactions on Mexican lime and presented high titer with specific monoclonal antibodies.

Similar SSCP banding patterns were also documented for the accessions 'Mac Carthy' (OC 324) and 'Retiro' (OC 329), and between 'De Maurítius' (NC 672) and 'Pamplemousse' (NC 673). These accessions belong to group 2 and showed mild stem pitting.
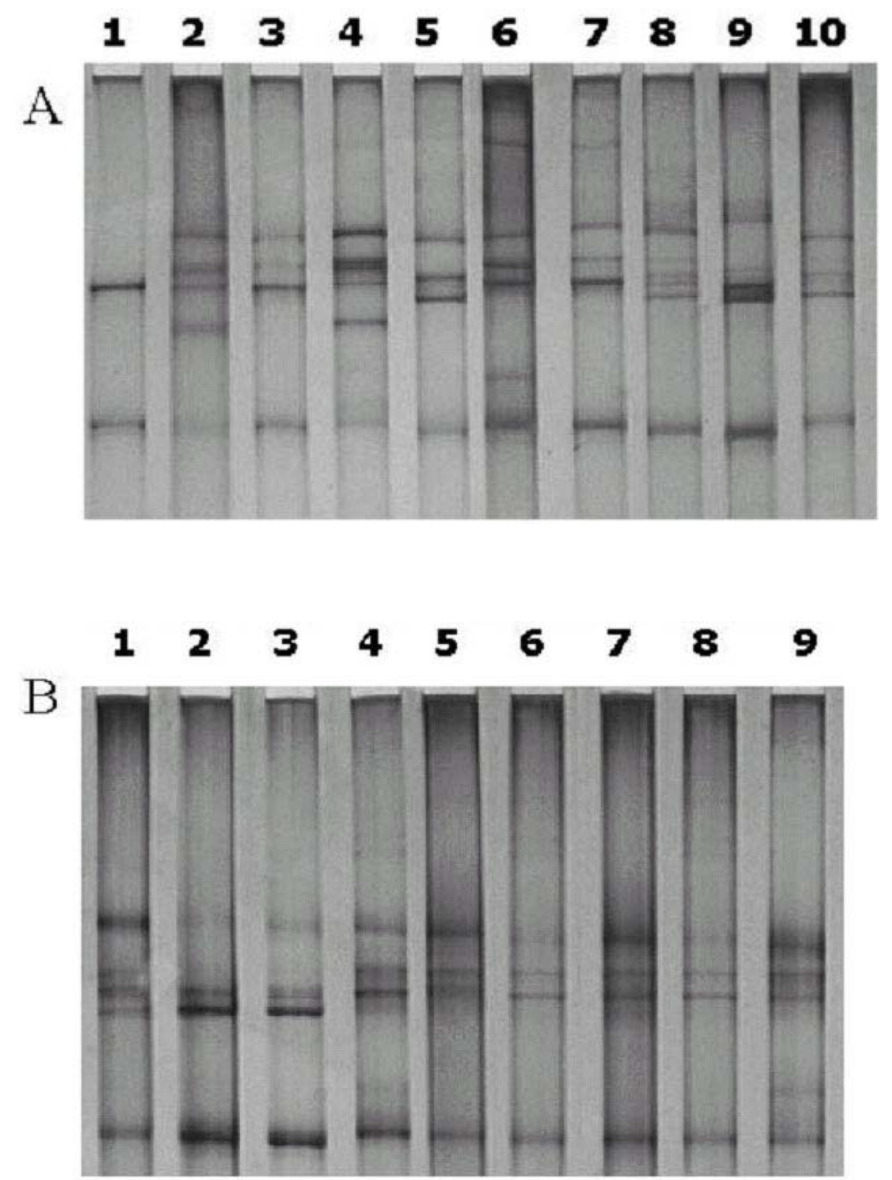

Figure 1. SSCP patterns of the capsid protein gene of the CTV isolates from grapefruit accessions from the AGB: A. Old Clone: 1Royal; 2-Rubi; 3-Redblush; 4-Red Mexican; 5-Triumph; 6-Thompson Pink; 7-Imperial; 8-Marsh Seedless; 9- Marsh Seedless 11650; 10Marsh Seedy. B. New Clone: 1- Marsh Seedless; 2-Coco Variação; 3 Arananyan; 4-Davis da Florida; 5-Marsh da Florida; 6-Shamber da Florida; 7-Redblush; 8- Marsh Seedless-São Sebastião; 9- Marsh Seedless- Limeira. Patterns followed by the same lowercase letter are simillar.
However, all the accesses reacted positively with all the specific monoclonais and not always it happens correlation among SSCP banding patterns and title of the virus.

The evidence obtained through the stem pitting symptoms, canopy volume analyses, immunological diagnosis with different monoclonal antibodies and SSCP analyses demonstrated that the different grapefruit accessions from the old and new clone collections from the IAC Citrus-AGB are infected with severe CTV isolates. The accesses of the group 2, that presented better performance in relation to the CTV, are not varieties of commercial importance. Therefore, considering that a commercial grapefruit variety from the IAC CitrusAGB needs to be used as mother tree, it must be "cleaned" from CTV by micro shoot grafting and than undergo the pre-immunization procedure.

Pre-immunization studies with grapefruit plants were conducted in Australia (3), South Africa (34), Japan (29), Florida (25) and Brazil (16). Many of the pre-immunized plant materials showed superior vigor and production when compared to the non-pre-immunized plants.

\section{REFERENCES}

1. Ballester-Olmos, J.F.; Pina, J.A.; Carbonell, E.A.; Moreno, P.; Hermoso de Mendonza, A.; Cambra, M.; Navarro, L. Biological diversity of citrus tristeza virus (CTV) isolates in Spain. Plant Pathology, London, v.42, p.219-229, 1993.

2. Beidler, L.L.; Hilliard, P.R.; Rill, R.L. Ultrasensitive staining of nucleic acids with silver. Analytical biochemistry, Maryland, v.126, p.374-380, 1982.

3. Broadbent, P.; Brlansky, R.H.; Indsto, J. Biological characterization of australian isolates of citrus tristeza virus and separation of subisolates by single aphid transmissions. Plant Disease, St.Paul, v. 80, p.329-333, 1996.

4. Carraro, B.P.; Nunes, W.M.C.; Corazza-Nunes, M.J. Machado, M.A.; Stach-Machado, D.R. Avaliação de complexos do Citrus tristeza vírus da região Norte do Paraná por meio de testes imunológicos e SSCP do gene da capa protéica. Acta Scientiarum, Maringá, v.25, p.269-273, 2003.

5. Carvalho, S.A.; Machado, M.A.; Baptista, C.R.; Müller, G.W.; Silvério, J.L. Caracterização biológica de isolados do vírus da tristeza dos citros. Fitopatologia brasileira, Brasília, v. 22, p.79-84, 1997.

6. Corazza-Nunes, M.J.; Machado, M.A.; Müller, G.W.; StachMachado, D.R.; Souza, A.A.; Nunes, W.M.C. Evaluation of citrus tristeza virus (CTV) complexes in preimmunized Marsh Seedless grapefruit. Summa Phytopathologica, Jaguariúna, v.27, p.11-16, 2001.

7. Domingues, E. T.; Tulmann Neto, A. Bancos de germoplasma de citros e sua importância para o melhoramento. Laranja, Cordeirópolis, v.19, p.343-364, 1998.

8. Garnsey, S. M.; Cambra, M. Enzyme-linked immunosorbent assay (Elisa) for citrus pathogens, p193 216. In: Roistacher, C.N. (Ed.). Graft-transmissible diseases of citrus - Handbook for detection and diagnosis. Rome: FAO, 1991. 286p.

9. Gillings, M.; Broadbent, P.; Indsto, J.; Lee, R.F. Characterization of isolates and strains of citrus tristeza closterovirus using restriction analysis of coat protein gene amplified by the polymerase chain reaction. Journal of Virological Methods, London, v.44, p.305317, 1993.

10. Huang, Z. Detection and isolate differentiation of Citrus tristeza 
virus in infected field trees based on reverse transcription-polymerase chain reaction. Plant Disease, St. Paul, v.88, p.625-629, 2004.

11. Kano, T.; Garnsey, S.M.; Koizumi, M.; Permar, T.A. Serological diversity of citrus tristeza virus (CTV) in Japan. In: Conference of the International Organization of Citrus Virologists, 11; 1991, Riverside. Riverside: Proceedings. IOCV, 1991. p.51-55.

12. Machado, M.A.; Stach-Machado, D.R.; Targon, M.L.P.N.; Baptista, C.R.; Carvalho,S.A.; Müller, G.W. Diagnóstico do vírus da tristeza dos citros com diferentes anticorpos monoclonais. Fitopatologia Brasileira, Brasília, v.22, p.191-194, 1997.

13. McClean, A.P.D. The tristeza virus complex. In: Conference of the International Organization of Citrus Virologists, 6; 1974, Riverside. Riverside: Proceedings. IOCV, 1974. p. 59-66.

14. Moreira, C.S.; Pio, R.M. Melhoramento de citros. In: Rodriguez, O.; Viégas, F.; Pompeu Junior, J.; Amaro, A. A. (Ed). Citricultura brasileira. Campinas: Fundação Cargill, 1991. v.1. p.117-152.

15. Müller, G.W.; Guirado, N.; Figueiredo, J.O.; Machado, M.A.; Laranjeira, F.F.; Castro, J.L. Citrus tristeza virus causes stem pitting in Rangpur Lime rootstock grafted with some Mandarin cultivars in Capão Bonito, Brazil. In: Conference of the International Organization of Citrus Virologists, 13; 1996, Riverside. Riverside: Proceedings. IOCV, 1996. p.325-328.

16. Müller, G. W.; Vega, J; Teófilo Sobrinho, J.; Pompeu, JR. J.; Nagai, V.; Costa, A.S. Resultados satisfatórios da premunização em pomelo 'Marsh Seedless'. Laranja, Cordeirópolis, v.12, p.235-246, 1991.

17. Nickel, O.; Santos Filho, H.P.; Vilarinhos, A.D. Segregation of citrus tristeza strains by graft propagation. In: Conference of the International Organization of Citrus Virologists, 13; 1996, Riverside. Riverside: Proceedings. IOCV, 1996. p.64-70.

18. Nikolaeva, O.V.; Karasev, A.V.; Garnsey, S.M.; Lee, R.F. Serological differentiation of the citrus tristeza virus isolates causing stem pitting in sweet orange. Plant Disease, St. Paul, v. 82, p.12761280, 1998.

19. Pappu, H.R.; Pappu, S.; Niblett, C.L.; Lee, R.F.; Civerolo E.L. Comparative sequence analysis of the coat protein of biologically distinct citrus tristeza closterovirus isolates. Virus Genes, New York, v.7, p.255-264, 1993.

20. Permar, T.A.; Garnsey, S.M.. Comparison of biological indexing and immunological assays for identifying severe Florida isolates of citrus tristeza virus. In: Conference of the International Organization of Citrus Virologists, 11; 1991, Riverside. Riverside: Proceedings. IOCV, 1991. p.56-59.

21. Permar, T.A.; Garnsey, S.M.; Gumpf, D.J.; Lee, R.F. A monoclonal antibody that discriminates strains of citrus tristeza virus. Phytopathology, St. Paul, v.80, p.224-228, 1990.

22. Pio, R.M. O banco ativo de germoplasma de citros do Instituto Agronômico. O Agronômico, Campinas, v.34, p.27-30, 1982.

23. Pompeu Junior, J. Estudo de comportamento de clones nucelares e velhos de laranjeira Hamlin (Citrus sinensis L. Osbeck) em dois porta-enxertos. 1972. 121 f. Tese (Doutorado/Fitotecnia) - Escola Superior de Agricultura Luiz de Queiroz, Universidade de São Paulo, Piracicaba.

24. Powell, C.A.; Pelosi, R.R.; Cohen, M. Superinfection of orange trees containing mild isolates of citrus tristeza virus with severe Florida isolates of citrus tristeza virus. Plant Disease, St. Paul, v.76, p.141-144, 1992.

25. Powell, C.A.; Pelosi, R.R.; Rundell, P.A.; Stover, E.; Cohen, M. Cross-protection of grapefruit from decline-inducing isolates of citrus tristeza virus. Plant Disease, St. Paul, v.83, p.989991, 1999.

26. Rocha-Penã, M.A.; Lee, R.F.; Lastra, R.; Niblett, C.L.; OchoaCorona, F.M.; Garnsey, S.M.; Yokomi, R.K. Citrus tristeza virus and its aphid vector Toxoptera citricida. Threats to citrus production in Caribbean and Central and North America. Plant Disease, St. Paul, v.79, p.437-445, 1995.

27. Rubio, L. Ayllon, M.A.; Ayllón, A.M.; Guerri, J.; Pappu, H.; Niblett, C.; Moreno, P. Differentiation of citrus tristeza closterovirus (CTV) isolates by single-strand conformation polymorphism analysis of the coat protein gene. Annals of Applied Biology, London, v.129, p.479-489, 1996.

28. Sambrook, J.; Fritsh, J.; Maniatis, T. Molecular Cloning: A laboratory manual. $2^{\text {nd }}$ Ed. Cold Spring Harbor Laboratory Press. 1989.

29. Sasaki, A. Control of Hassaku dwarf by preimmunization with mild strain. Review Plant Protection Research, v.12, p. 80-87, 1979.

30. Souza, A.A.; Müller, G.W.; Targon, M.L.P.N.; Machado, M.A. Evalution of changes which occurred in a mild protective citrus tristeza virus isolate in pera sweet orange trees by using RFLP and SSCP analyses of the coat protein gene. In: Conference of the International Organization of Citrus Virologists, 14; 2000, Riverside. Riverside: Proceedings. IOCV, 2000. p.136-140.

31. Stach-Machado, D.R.; Targon, M.L.P.N.; Arruda, G.; Barbosa, R.A.; Barreto, M. J.; Wagner, G. A.; Machado, M. A. Obtenção de anticorpos monoclonais para avaliação do complexo 'Capão Bonito' do vírus da tristeza dos citros (CTV). Fitopatologia Brasileira, Brasília, v.23, p.319, 1998. (Resumo).

32. Targon, M.L.P.N. Expressão e análise do gene do capsídeo de isolados do vírus da tristeza em diferentes espécies e variedades de citros. 1997. 142 f. Tese (Doutorado/Ciências Biológicas) Universidade Estadual de Campinas, Campinas.

33. Valverde, R.A. Analysis of double strand RNA for plant virus diagnosis. Plant Disease, St. Paul, v.71, p.255-258, 1990.

34. Van Vuuren, S.P., Collins, R.P.; Da Graça, J.V. Evaluation of citrus tristeza vírus isolates for cross protection. Plant Disease, St. Paul, v.77, p.24-48, 1993.

35. Vega, J., Müller, G.W.; Cambra, M. Diferenciação de isolados brasileiros do vírus da tristeza dos citros através de anticorpos monoclonais. Fitopatologia Brasileira, Brasília, v.18, p.273, 1993. (Resumo). 